OPEN ACCESS

Edited by:

Anoop Ambili,

Indian Institute of Science Education and Research Mohali, India

Reviewed by: John Dodson, Institute of Earth Environment (CAS),

China

Mahesh Thakkar, Krantiguru Shyamji Krishna Verma Kachchh University, India

*Correspondence: Amzad Hussain Laskar amzad@prl.res.in

Specialty section: This article was submitted to Interdisciplinary Climate Studies, a section of the journal

Frontiers in Earth Science

Received: 13 May 2021

Accepted: 20 July 2021

Published: 06 September 2021

Citation:

Laskar AH and Bohra A (2021) Impact of Indian Summer Monsoon Change on Ancient Indian Civilizations During

the Holocene.

Front. Earth Sci. 9:709455. doi: 10.3389/feart.2021.709455

\section{Impact of Indian Summer Monsoon Change on Ancient Indian Civilizations During the Holocene}

\author{
Amzad Hussain Laskar ${ }^{1 *}$ and Archna Bohra ${ }^{2}$ \\ ${ }^{1}$ Geosciences Division, Physical Research Laboratory, Ahmedabad, India, ${ }^{2}$ CSIR-National Geophysical Research Institute, \\ Hyderabad, India
}

A large part of South Asia receives rainfall mainly during the Indian Summer Monsoon (ISM) season of the year (Jun-Sep). The socioeconomic conditions of most of the developing countries in this region largely depend on the ISM rains. It also played important roles in rise and collapse of ancient civilizations in this region. However, the influence of the ISM on Indian ancient civilizations has not yet been fully explored though there were some attempts to correlate monsoon variation with their rise and fall. For example, in the mid to late Holocene period, Indus Valley or Harappan Civilization flourished in the western part of India from its early development, through its urbanization and eventual transformation into a rural society. Probably a prolonged decrease in the ISM rainfall caused the decline in the urban phase of the Indus Civilization around the $4.2 \mathrm{kyr} \mathrm{BP}$ global climate event. Another well-recorded early Holocene global climate event is the $8.2 \mathrm{kyr}$ BP cooling event which also reportedly influenced ISM significantly, but its impact on human settlement is not clear in this region. The present study is a comprehensive review of the archaeological and climatological researches carried out on the role of ISM variability on the rise and fall of ancient Indian civilizations for the most part of the ongoing interglacial period, the Holocene. The review covers the studies on the period of the last $10 \mathrm{kyr}$ as evidence suggests that human settlement and cultural developments in this region started around the beginning of this period. We have noted that the existing studies are mostly restricted to vague qualitative analysis of the weakening/strengthening of the ISM, and researches related to quantitative estimations of changes of the monsoon strengths and durations of drought events that caused collapse of civilizations are limited. Therefore, in the present analysis, emphasis has also been given on the requirement of estimating the absolute changes that might have caused cultural shifts. Some possible ways to quantitatively estimate the changes of some climate parameters are discussed.

Keywords: ancient civilization, Indian summer monsoon, paleoclimate records, stable isotopes, Holocene

\section{INTRODUCTION}

\section{A Brief History of Ancient Civilizations in the Indian Subcontinent}

There is a long history of rise and fall of civilizations in the Indian subcontinent. The existing records indicate that there was human occupation in North India about $30 \mathrm{kyr}$ BP (Singh et al., 1999) though settled life probably started around early Holocene time. The old Indian civilizations were mostly developed on alluvium (Giosan et al., 2012; Macklin and Lewin, 2015), in dry environments with their farming dependent on natural inundation or controlled irrigation from river water. These early 
civilizations were vulnerable to political as well as environmental stresses, and the factors responsible for the decline and collapse of many of them have been debated (McAnany and Yoffee, 2010; Butzer, 2012). From the climatological point of view, some major causes of cultural abandonment were prolonged drought, e.g., the Indus (Staubwasser et al., 2003; Giosan et al., 2012; Kathayat et al., 2017), destructive floods, e.g., Huang He (Kidder et al., 2012), abrupt reductions in river flow and river water availability, e.g., Nile in Nubia (Macklin et al., 2013), and prolonged salinization of soil, e.g., Euphrates (Jacobsen and Adams, 1958). Available studies mostly point to climate change or, more precisely, significantly low ISM rainfall for a prolonged period of many years as the cause of the collapse of the ancient Indian civilizations.

Agricultural practices in Central India probably started around early Holocene. Based on pollen analysis, Quade et al. (2013) suggested that the agricultural activity in Madhya Pradesh, India, started about $9 \mathrm{kyr}$ BP. The authors also observed humid conditions and increased agricultural activities between 7 and $4 \mathrm{kyr}$. Evidence of transformation from hunter-gathering to communities with settled agriculture and domestication of animals was reported at Mehrgarh (now in Pakistan) around the early phase of Holocene. The earliest available settlement at Mehrgarh dates back to $~ 9$ kyr BP (Jarrige and Lechevallier, 1979; Jarrig, 1981; Jarrig, 1993) which coincides with a humid phase of the ISM (Fleitmann et al., 2003; Gupta, 2004). Existence of agricultural activity in central India about $7 \mathrm{kyr}$ BP was also reported by Yadava et al. (2007) based on earth burns, charcoals, and plant remains observed in a limestone cave located in Chhattisgarh, India. Archaeological evidence of cultivation of grains in southern Asia around 9 kyr BP was reported by Kulke and Rothermund (2004). Therefore, settled life at least in some parts of India and transition from foraging to farming and pastoralism started in early Holocene time. However, it is very complex to identify the transition time from foraging to farming in south Asia as pointed out by BarkerRichards et al. (2013) particularly due to scarcity of archaeological data. Relatively more proxy data and extensive analysis are available from the mid Holocene onward during which the region witnessed many interesting phenomena related to both climate change and archaeology as discussed below.

One of the most well-documented advanced civilizations in the subcontinent is the Harappan or Indus Valley Civilization (Kenoyer, 1997; Kenoyer, 1998; Possehl, 2002a; Madella and Fuller, 2006; Wright, 2009; Gangal et al., 2010; MacDonald, 2011; Giosan et al., 2012; Sarkar et al., 2016; Sengupta et al., 2019) which developed at the arid outer belt of ISM dominated region (Figure 1). The Harappan Civilization that flourished in the north western part of the Indian subcontinent was probably the largest among the $10 \mathrm{kyr}$ Bronze Age Civilizations. The Harappan culture started evolving from $\sim 5.5 \mathrm{kyr}$ BP from preceding agricultural communities in the Indus alluvial plain and reached to its urban peak, i.e., mature phase during 4.5-3.9 kyr BP (Sengupta et al., 2019). The Harappans were agrarian though they were advanced in trading and architecture and designed sophisticated materials including weapons. Unlike other contemporary civilizations, Harappans probably did not attempt to control water resources by large-scale canal irrigation (Schumm, 2007). Deurbanization of Harappa or dispersion into smaller groups happened after $3.9 \mathrm{kyr} B P$, indicated by disappearance of the special Harappan script and appearance of regional artefact and trading activities (Kenoyer, 1998; Possehl, 2002a; Kenoyer, 2006; Wright, 2009; Sengupta et al., 2019). This is often referred to as the collapse of the Harappan Civilization. The Harappan Civilization perhaps flourished on the bank of the mythological river Saraswati. The existence of the Saraswati/Ghaggar has been established recently by Chatterjee et al. (2019) using geochemical and isotopic proxies. The authors inferred that the river was active in the region for two periods in the past, namely, 80-20 and 9.4-4.5 kyr, the timing of the ultimate decline of the river coincides with the collapse of the Harappan Civilization around the beginning of the Meghalayan Stage. Causes of decline of civilizations are elaborated in Influences of ISM on the Ancient Civilizations in Indian Subcontinent.

After Harappa or contemporary to it, another civilization flourished in the Indian subcontinent called the Vedic Civilization approximately between 4 and $2.5 \mathrm{kyr}$ BP (Pruti, 2004). Some researchers argued that the Vedic Civilization also existed in the banks of the mythological river Saraswati that was flowing in the region between Indus River in the west and Aravalli Mountain range (Singhvi and Kar, 1992; Chauhan, 1999) and claimed to be even older than the Harappa (e.g., Radhakrishna and Merh, 1999; Paliwal, 2011). However, most consensus is that the Vedic Civilization flourished between 3.5 and 2.5 kyr BP (Samanta et al., 2011). Vedic is the first historic civilization which has some written records and the name Vedic came from Vedas, the early literature of Vedic people. Unfortunately, its relation with Harappan is not well established. Initial Vedic culture was nomadic in nature with cattle rearing as their main occupation along with cropping practices. The later phase was dominated by agricultural activities governing the economy with decline in cattle rearing and emergence of relatively large kingdoms (Pruti, 2004).

\section{Indian Summer Monsson, Its Importance, Causes, and Consequences of Its Variation}

The Indian Summer Monsoon (ISM) is a synoptic scale weather system and strongly impacts and contributes to shaping the socioeconomic and cultural advancement in South Asia. It is a manifestation of the seasonal migration of the Intertropical Convergence Zone (ITCZ) (Webster et al., 1998; Gadgil, 2018). It strongly affects the hydroclimatic conditions which in turn strongly impacts the food-grain production and the Gross Domestic Product (Gadgil and Gadgil, 2006) of nearly a quarter of the global human population living in this region. Slight variations in ISM strength or its delay in the historic past caused many serious impacts on humans in economic as well as ecological aspects caused by floods and droughts (Shewale and Kumar, 2005; Cook et al., 2010; Laskar et al., 2010, Laskar A. et al., 2013a; Sridhar et al., 2015; Dutt et al., 2018; Dutt et al., 2019; Kotlia et al., 2018; Gupta et al., 2020). In the Holocene, the region experienced many droughts, mega droughts, and extreme 
A

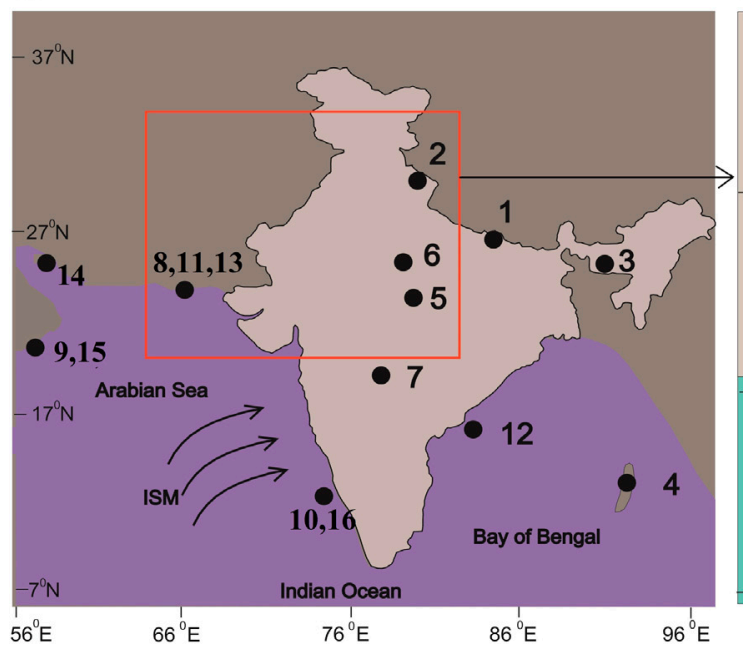

B



FIGURE 1 | (A) Map of India and its surroundings with filled circles showing the approximate locations of the sites from which the data of the proxy records are presented in Figures 2, 3: 1) Ali et al. (2018), 2) Kathayat et al. (2016), 3) Berkelhammer et al. (2012), 4) Laskar A. H. et al. (2013b), 5) Dixit et al. (2014a), 6) Dixit et al. (2014b), 7) Prasad et al. (2014), 8) Staubwasser et al. (2002), 9) Gupta et al. (2003), 10) Tiwari et al. (2015), 11) von Rad et al. (1999), 12) Ponton et al. (2012), 13) Pichevin et al. (2007), 14) Sirocko et al. (1993), 15) (Altabet et al., 2002), and 16) Saraswat et al. (2013). (B) Regions showing the Indus Valley Civilization settlement along with major rivers. Some major excavation sites are shown by filled squares. Redrawn following Green (2021).

flooding observed by many paleoclimate researchers (Berkelhammer et al., 2010; Buckley et al., 2010; Cook et al., 2010; Sinha et al., 2011; Dixit and Tandon, 2016; Kathayat et al., 2018; Sharma et al., 2021). Many of these major climatic events are believed to cause collapse of ancient civilizations. Even in the last decade many such extreme events such as the Kedarnath flood in 2013; Kerala flood in 2019; and floods in Assam, Maharashtra, and Gujarat and glacier burst in Uttarakhand in 2021 caused severe human and financial loss (Dobhal et al., 2013; Singh et al., 2014; Rana et al., 2021). These extreme events may further intensify with greater magnitude in different geographical localities in the future with global warming (IPCC, 2013), thus jeopardizing planning strategies. Therefore, detailed analyses of the ISM in the past and how it influenced ancient inhabitants are required to understand its possible impacts. Though model forecasting and better technology would help to take preparation and minimization of loss in case any such situation arises in future, still a better understanding of the past may help to handle possible impacts in the future.

The Holocene is the current warm geological epoch, established around $11.5 \mathrm{kyr} \mathrm{BP}$ after the last glacial period. Warming during the Holocene has been associated with the increased solar insolation also termed as the Holocene Thermal Maxima (HTM). However, the temperature increase was punctured by some global cooling events. For example, events at 8.2 and $4.2 \mathrm{ka}$ are identified as globally dry cool climates (Staubwasser et al., 2003; Liu et al., 2013; Dixit et al., 2014a; Dixit et al., 2014b; Banerji et al., 2020) though the exact reason for these relatively abrupt climate events remain elusive. The $8.2 \mathrm{kyr}$ even was probably caused by weakening of the North Atlantic Deep Water formation resulting in the change in the Atlantic Meridional Overturn Circulation (Barber et al., 1999). The driving force behind the weakening of the North Atlantic Deep water formation was probably the glacial outburst of freshwater from Lake Agassiz into the
North Atlantic (Bauer et al., 2004). The 4.2 kyr event, a multidecadal to century scale event over an extensive region (e.g., Cullen et al., 2000; Drysdale et al., 2006; Dixit et al., 2014a; Mehrotra et al., 2018), points to a global megadrought (Weiss, 2016). This event has been accepted as the formal boundary of late and middle Holocene at the global scale and the period after $4.2 \mathrm{kyr}$ is called the Meghalayan age. Despite its wide spread recognition, the timing, duration, its origin in terms of changes in ocean and atmospheric circulation remain intangible. Moreover, many of the paleoclimate records do not show the evidence of the $4.2 \mathrm{ka}$ event, at least as a major event of the mid-late Holocene (e.g., Seppa et al., 2009; Roland et al., 2014) and not necessarily as a cold and dry event (e.g., Railsback et al., 2018) indicating spatial variation in its impact. For example, in the regions affected by ISM, the $4.2 \mathrm{kyr}$ event is not obvious in all proxy records and in the records where it is observed is mostly shown as weak ISM rather than cooling (e.g., Siroko et al., 1993). Some researchers suggested that this event is not just a single long dry event but a complex succession of dry/wet events, (Magny et al., 2009; Railsback et al., 2018). In the Mediterranean region, it is mostly considered as a dry interval as observed in many proxy records in speleothems (Drysdale et al., 2006; Zanchetta et al., 2016; Finné et al., 2017), pollen (e.g., Magri and Parra, 2002; Di Rita and Magri, 2009; Kaniewski et al., 2013), lake sediments (e.g., Zanchetta et al., 2012), and marine sediments (e.g., Margaritelli et al., 2016). Moreover, the exact timing of the event differs across proxy records (Finné et al., 2011), challenging the view that it is a global period of significant drought. Other regional to global climate events observed during the late Holocene period include the Roman Warm Period, Medieval Warm Anomaly, the Little Ice Age, and the modern warm period that influenced ISM rainfall significantly (Laskar A. H. et al., 2013b; Liang et al., 2015; Kotlia et al., 2017). Some of these events are consistent in many proxy records while some others are missing in 
some archives indicating their variations from region to region and nonuniform effects on different proxies. These seasonal to multidecadal climate anomalies are associated with El-Nino Southern Oscillation, Indian Ocean Dipole, North Atlantic Oscillation, Pacific Decadal Oscillation, Inter Decadal Pacific Oscillation, and Indo-Pacific Warm Pool. However, the effects of most of these forces on ISM are nonstationary (e.g., Krishna Kumar et al., 2006). Though these late Holocene climatic phenomena have drastic influence on the socioeconomy of the subcontinent and south Asian countries as discussed earlier, their effect on settlement/displacement of human civilization is probably not that severe to cause collapse of a civilizations as happened in the early to mid Holocene and hence not discussed in detail here.

The present work is an attempt to assess the details of the ISM variation in the last $10 \mathrm{kyr}$ to understand its role on the rise and fall of civilizations in the north-western region of the Indian subcontinent. This is carried out by compiling the major available studies from the regions influenced by ISM during the Holocene. This study will serve to identify gaps in the regional coverage, to determine if coherent regional/subregional climatic patterns are present and expose aspects that should be addressed in future research on this topic. Another important purpose of the study is to explore the possibility of estimating quantitatively the variations of some of the past climate parameters using some recently developed proxies.

\section{PROXY CLIMATE RECORDS}

There are multiple terrestrial and marine paleoclimate records, sensitive to changes in climate parameters available in the Indian subcontinent and surrounding regions. The present review is mainly focused on stable isotope-based proxy records obtained from oceanic and terrestrial sediments, alluvial deposits, and speleothems. The proxy records used in this review are selected on the basis of length, temporal resolution, dating quality, data interpretability, and geographic distribution. Preferences are given to the records with a full Holocene coverage that attempted to quantitatively estimate climate parameters (e.g., rainfall for ISM strength), better temporally resolving data with relatively better constrains in chronology, directly associated with one or more climate variables and geographical distribution. Locations of the proxy records included and analysed in this review are shown in Figure 1. All records that suit the foregoing requirements are not included, but this collection represents a substantial set of data that can serve as a base for furthering a focused study related to climate change and archaeology.

\section{RESPONSE OF INDIAN SUMMER MONSOON TO GLOBAL AND LOCAL CLIMATIC EVENTS DURING THE HOLOCENE}

Although climate variability during the Holocene is smaller in amplitude compared to the large shifts of the last glacial cycle, they are large enough to play a major role in rise and collapse the human civilizations in various parts of the globe (e.g.,
Staubwasser et al., 2003; Prasad et al., 2014; Pokharia et al., 2014; Kathayat et al., 2017). A number of climate perturbations have been identified during the Holocene. For example, the early Holocene atmospheric warming, the $8.2 \mathrm{kyr}$ event, the $4.2 \mathrm{kyr}$ event, the Medieval Climate Anomaly, the Roman Warm Period, the Little Ice Age, and the current warm period are widely recognized climate phenomena observed during the Holocene (Gupta et al., 2003; Mayewski et al., 2004; Cheng et al., 2009; Buckley et al., 2010; Laskar et al., 2013b; Dixit et al., 2014a; Dixit et al., 2014b; Dutt et al., 2015; Kathayat et al., 2018; Kotlia et al., 2018). Based on major global abrupt climate events, the Holocene period has been divided into three substages, namely, Greenlandian (11.5-8.2 kyr), Northgrippian (8.2-4.2 kyr), and Meghalayan (4.2 kyr to AD 1950) (Walker et al., 2018; Walker et al., 2019). ISM rainfall during the early Holocene (11-7 kyr BP) was significantly higher than present and was linked to Himalayan snow cover and North Atlantic sea surface temperature along with the northward migration of the ITCZ (Wang et al., 2005; Fleitmann et al., 2007). ISM weakened around $8.2 \mathrm{kyr}$ with retreat of the ITCZ southwards, reduction of the northern hemisphere ice sheet, and stabilization of the Thermohaline circulation. The subsequent monsoon strength was mainly controlled by solar insolation and position of the ITCZ. Different oceanic basins modulate ISM through ocean-atmosphere teleconnections. ISM rainfall exhibited a multidecadal oscillation mode with a significant coherence with that of the Atlantic Multidecadal Oscillation (Goswami et al., 2006).

The two well-documented global events at 8.2 and $4.2 \mathrm{kyr}$ BP are identified as dry or cool climates, the onset of Northgrippian and Meghalayan stages, respectively (Barber et al., 1999). The cooling event at $8.2 \mathrm{kyr}$ BP affected climate throughout the Northern Hemisphere and in Greenland (Thomas et al., 2007; Cheng et al., 2009; Liu et al., 2013; Banerji et al., 2020). Using $\delta^{18} \mathrm{O}$ and $\mathrm{Mg} / \mathrm{Ca}$ measurements of a speleothem, Liu et al. (2013) showed that climate was significantly drier $\sim 8.2 \mathrm{kyr}$ ago and lasted for 150 years, with 70 years of pronounced aridity. The timing and duration of the event corresponded with that observed in the Greenland ice cores, indicating a rapid atmospheric teleconnection between the North Atlantic and the ISM. Oxygen isotope ratios $\left(\delta^{18} \mathrm{O}\right)$ in speleothems from the ISM impacted regions also indicated a pronounced weakening of the Asian and Indian monsoons at $8.2 \mathrm{kyr}$ BP that probably lasted for 100-150 years (Fleitmann et al., 2003; Cheng et al., 2009; Liu et al., 2013). Lake sediment biogenic carbonate $\delta^{18} \mathrm{O}$ values from north-western India indicated weakening of the ISM around 8.2 kyr BP (Dixit et al., 2014b). This weakening was linked to the cooling of the North Atlantic (Staubwasser et al., 2002; Gupta et al., 2003; Cai et al., 2012) when temperatures fell by $\sim 3^{\circ} \mathrm{C}$ within a couple of decades (Kobashi et al., 2007).

The cooling and arid event around $4.2 \mathrm{kyr}$ BP has also been reported from various parts of the globe (e.g., Cullen et al., 2000; Staubwasser et al., 2003; Drysdale et al., 2006; Berkelhammer et al., 2012; Dixit et al., 2014a; Kathayat et al., 2018; Railsback et al., 2018). This event has been recognized in middle low latitude regions in many paleo climate records from North America, South America, Africa, China, and Antarctica 
(Mayewski et al., 2004; Staubwasser and Weiss, 2006). Many archaeological studies also indicated that the $4.2 \mathrm{kyr}$ event was associated with cultural shifts in Africa, the Mediterranean, Middle East, and South and East Asia (e.g., Weiss et al., 1993; Enzel et al., 1999; Cullen et al., 2000; Staubwasser et al., 2003; Liu and Feng, 2012; Weiss, 2016; Kathayat et al., 2017). It is believed that the $4.2 \mathrm{kyr}$ event played a major role in the decline of the Bronze Age Civilizations, including the Egyptian Old Kingdom (Stanley et al., 2003; Ramsey et al., 2010), the Akkadian Empire in Mesopotamia (Weiss et al., 1993; Cullen et al., 2000; Weiss et al., 2012), Longshan culture in China (Chauhan, 1999; Liu and Feng, 2012), and Harappan Civilization in the Indian subcontinent (Staubwasser et al., 2003; Berkelhammer et al., 2012; Dixit et al., 2014a; Kathayat et al., 2017; Sengupta et al., 2019). The $4.2 \mathrm{kyr}$ event from the ISM domain has been observed in speleothem $\delta^{18} \mathrm{O}$ measurements from Mawmluh Cave, Meghalaya, and Northeast India (Berkelhammer et al., 2012). This record was used to define the period after $4.2 \mathrm{kyr}$ as the Meghalayan Age (Walker et al., 2018). A number of proxy records from the Indian subcontinent suggest that a major weakening of the ISM occurred around or after the $4.2 \mathrm{kyr}$ event (Staubwasser et al., 2003; Berkelhammer et al., 2012; Laskar A. H. et al., 2013b; Dixit et al., 2014a; Nakamura et al., 2016; Kathayat et al., 2017). The $4.2 \mathrm{ka}$ event was generally described as drought for a duration of two to three centuries (e.g., Berkelhammer et al., 2012; Dixit et al., 2014b; Nakamura et al., 2016). The influence of $4.2 \mathrm{kyr}$ event on ISM is discussed in more detail in Discussion.

Many other relatively smaller magnitude climate events impacted the ISM during the late Holocene (Laskar et al., 2010; Laskar et al., 2013a; Laskar et al., 2013b). For example, over the Bay of Bengal region, speleothem $\delta^{18} \mathrm{O}$ records suggest a declining trend of ISM strength during $4-2.1 \mathrm{kyr} B P$ and enhancement during 2.1-0.8 kyr BP, and during the transition from Medieval Climate Anomaly to the Little Ice Age (0.8-0.4 kyr BP) (Laskar A. H. et al., 2013b). The Central Himalayan region experienced a decline of ISM strength during 4-3 kyr BP and enhancement during 3-2 kyr and large fluctuations during 2.0-0.8 kyr BP and then an increase after $0.8 \mathrm{kyr}$ BP (Kotlia et al., 2017; Kotlia et al., 2018). These studies suggest that the global climatic epochs have a varying degree of influence on monsoonal activity over different Indian regions. However, assessment of their influences on the human settlement/ dispersion needs both high resolution archaeological and climate change data.

\section{INFLUENCES OF INDIAN SUMMER MONSOON ON THE ANCIENT CIVILIZATIONS IN INDIAN SUBCONTINENT}

The previous perspective that Holocene climate was stable has changed with the availability of high-resolution paleoclimate records (Fleitmann et al., 2003; Gupta et al., 2003; Buckley et al., 2010; Laskar A. H. et al., 2013b). As discussed before, the Holocene witnessed many climatic events which largely impacted the human societies, vegetation, and ecology. Researchers linked many of these climatic events with the shifts of cultures in different parts of the world. However, such linkage of climate with the establishment and collapse/ displacement is intensely debated due to lack of direct evidence. It is believed that abrupt and/or prolonged drought conditions led the collapse or forceful migration of many cultures mainly by affecting food and water availability (Cullen et al., 2000; Buckley et al., 2010; Liu and Feng, 2012; Dixit et al., 2014a; Kathayat et al., 2017). For example, in Tell Sabi Abyad, a Neolithic archaeological site in northern Syria, a significant cultural change was observed around $6200 \mathrm{BC}(\sim 8.2 \mathrm{kyr}$ BP) (Balter 2010; van der Plicht et al., 2011). Evidence of many such cultural shifts has been reported in Europe and Near East associated with the aridification around the $8.2 \mathrm{kyr}$ event (e.g., Migowski et al., 2006; Staubwasser and Weiss, 2006; Weninger et al., 2006; Budja, 2007; Berger and Guilaine, 2009; Gronenborn, 2009; Wicks and Mithen, 2014). However, evidence of cultural changes related to the $8.2 \mathrm{kyr}$ event in the Indian subcontinent is limited by the lack of data. Though there is evidence of changes in the ISM rainfall around $8.2 \mathrm{kyr}$ and some sparse evidence of human settlements in the Indian subcontinent during the early Holocene as discussed earlier, the impact of the reduction of ISM strength around the $8.2 \mathrm{kyr}$ event on early Holocene human settlements is unclear.

Impacts of ISM on the mid to late Holocene Indian civilizations are generally accepted as fact. The Harappan Civilization, established around the early-mid Holocene in the Indian subcontinent, was one of the most advanced Bronze Age Civilizations. The establishment and growth of this civilization started during the phase of higher precipitation from a strong ISM. Kathayat et al. (2017), based on speleothem $\delta^{18} \mathrm{O}$ record from Sahiya cave, showed that the mature phase of Harappan culture was the period between 4.5 and $3.9 \mathrm{kyr}$ BP, occurred during a wet and warm climate. Probably the optimum climate helped in agricultural activities and urban developments for the Harappans. However, the disappearance of this civilization has been a long debated subject. Evidence suggests that the decline/ displacement of the civilization started around $4.2 \mathrm{kyr}$ B.P probably caused by a significant decrease in ISM precipitation resulting in insufficient moisture availability in the region to support the agricultural needs of the population (Enzel et al., 1999; Staubwasser et al., 2003; Berkelhammer et al., 2012; Dixit et al., 2014a). The deurbanization of the Harappan Civilization after the $4.2 \mathrm{kyr}$ event has been discussed widely (e.g., Possehl, 2002b; Ratnagar, 2002; Kulke and Rothermund, 2004; Lawler, 2008; Wright, 2009; Petrie et al., 2017). Some initial researchers also suggested foreign invasions (e.g., Aryan invasions) into India, societal instabilities, and a decline of trade (Possehl, 2002b) as causes, but no strong evidence supporting them exists (Fitzsimons, 1970). Environmental factors such as regional aridification, hydrological changes such as reduction in water flow in the main river channel, the Ghaggar-Hakra system (Kenoyer, 1998; Radhakrishna and Merh 1999; Possehl, 2002a; Fuller and Madella, 2002; Wright et al., 2008; Sengupta et al., 2019), and land degradation due to human activity (Fairservis, 1967; Atkins et al., 1998) were also suggested to play major roles in the decline of Harappan Civilization (Kenoyer, 1998; Possehl, 2002b; MacDonald, 2011). Kathayat et al. (2017) argued that a 
multicentennial trend of relatively drier and cooler conditions in the Harappan region that started $\sim 4.1 \mathrm{kyr}$ ago was associated with the deurbanization phase during 3.8-3.3 kyr BP. In addition, reduced river flows in the region around this time in response to decrease in ISM rainfall over the Himalayan region were also observed (Singh et al., 1990; Phadtare, 2000). Therefore, the most plausible reason for the deurbanization/decline of the Harappan Civilization is related to climate rather than other societal related causes. Probably a combined influence of the reduction of ISM rainfall and reduced discharge from the Himalayan glaciers due to colder condition and weak ISM caused decline and forceful migrations of the Harappan settlers. Many groups probably continued after $3.9 \mathrm{kyr}$ BP but in reduced sizes (Mughal, 1997; Kenoyer, 1998; Possehl, 2002a). The post-Harappan urban phase witnessed establishment of smaller agricultural and pastoral communities especially in the Himalayan foothills and western part of the Ganges basin as indicated by abundant Neolithic and Chalcolithic settlements (Kenoyer, 1998; Possehl, 2002b; Korisettar et al., 2002; Panja, 2002; Singh, 2002; Kumar, 2009; Wright, 2009; Gangal et al., 2010).

The Vedic Civilization probably ended around 2.4 kyr BP and was marked by linguistic, cultural, and political changes, as well as eastward migrations (Witzel, 1987; Kulke and Rothermund, 2004). However, it is not well established how Vedic Civilization collapsed. According to Paliwal (2011), the Vedic Civilization collapsed due to climate changes and neotectonic activities that caused wide-spread salinization of soils and formation of saline lakes in the green fertile regions of the Vedic settlements. The weak ISM during the Roman Warm Period around 2 kyr BP (e.g., Laskar A. H. et al., 2013b) could be one of the causes of the decline of the Vedic Civilization. There is some speculation that the great war of Mahabharata caused the collapse of Vedic Civilization around $2 \mathrm{kyr}$ BP, though evidence to support this is unreliable.

\section{DISCUSSION}

Some available prominent proxy records from terrestrial and oceanic archives in and around the Indian subcontinent that are sensitive to changes in the ISM strengths along with solar changes are discussed here. The major changes of the ISM observed in the proxy records and that coincided with the global climate events and collapse of civilizations are highlighted. Solar insolation data at $65^{\circ} \mathrm{N}$, tropical temperature anomaly between $30^{\circ} \mathrm{S}$ and $30^{\circ} \mathrm{N}$, and some continental proxy records from regions affected by ISM are shown in Figure 2 (see Figure 1 for locations of proxy records). The rainfall variation, derived using $\delta^{13} \mathrm{C}$ in soil organic matter from a site from North Sikkim of Himalayan region, influenced by ISM strength is shown in Figure 2C (Ali et al., 2018). The annual rainfall is reconstructed based on an inverse relation between $\delta^{13} \mathrm{C}$ values of the plants and rainfall (Kohn, 2010). In the Ganga plain, it is observed that the $\delta^{13} \mathrm{C}$ values in modern $\mathrm{C}_{3}$ vegetation increase by $\sim 0.4 \%$ for a decrease in annual rainfall of $100 \mathrm{~mm}$ (Basu et al., 2015). For the last $10 \mathrm{kyr}$, it is clear that the ISM rainfall was high during the early Holocene (10.0-8.5 kyr) and decreased after $8.5 \mathrm{kyr}$ BP. The annual rainfall was relatively low during the mid Holocene and again increased in the late Holocene from $3 \mathrm{kyr} \mathrm{BP}$ onward. The lowest rainfall observed during 4.8-3.9 kyr BP ( $25 \%$ lower compared to the average of the last $1 \mathrm{kyr}$ ) probably coincides with the global $4.2 \mathrm{kyr}$ event. The significantly lower rainfall probably caused the collapse/ migration of the Harappan settlers. Also the strong decrease in annual rainfall after $8.5 \mathrm{kyr} \mathrm{BP}$ probably coincides with the global $8.2 \mathrm{kyr}$ event. Figure 3D shows the stalagmite $\delta^{18} \mathrm{O}$ variation from Sahiya cave, Uttarakhand, North India for the last $5.7 \mathrm{kyr}$ (Kathayat et al., 2017). Speleothem $\delta^{18} \mathrm{O}$ is sensitive to the changes in the ISM derived rainfall in the region (Yadava et al., 2004; Sinha et al., 2015; Band et al., 2018). A sharp increase in the $\delta^{18} \mathrm{O}$ values after $\sim 4 \mathrm{kyr} \mathrm{BP}$ is probably related to the decrease in the rainfall in response to the $4.2 \mathrm{kyr}$ event. A slight difference in timing could be due to spatial variation of the influences of the ISM and differences in chronological precision. A decrease in rainfall around $4.2 \mathrm{kyr} \mathrm{BP}$ is also evident from the stalagmite $\delta^{18} \mathrm{O}$ values from Mawmluh cave, Meghalaya, NE India (Figure 2E) (Berkelhammer et al., 2012). This indicates that the $4.2 \mathrm{kyr}$ event was wide spread in the ISM-dominated regions. However, around the $8.2 \mathrm{kyr}$ event, the $\delta^{18} \mathrm{O}$ values indicate an increase in the ISM strength from the same cave unlike many other parts of the subcontinent. This region, having the highest rainfall in the world (Cherrapunji and Mawsynram are located here), due to its orography, has a different rainfall pattern than the ISM alone and probably from ISM rainfall pattern in the past as well. Influences of various climate events on ISM strength during late Holocene are shown in Figure 2F with high resolution stalagmite $\delta^{18} \mathrm{O}$ values from Andaman Islands (Laskar A. H. et al., 2013b). All the major climate anomalies are reflected in the speleothem $\delta^{18} \mathrm{O}$ values. These include decrease in ISM rainfall during Roman Warm Period (2.1-1.8 kyr BP) and transition from Medieval Warm Climate to the Little Ice Age (0.8-0.4 kyr BP) and increase during Medieval Warm Climate (1.2-0.8 kyr BP). The decreased rainfall around $4.2 \mathrm{kyr} \mathrm{BP}$ and a sharp increase after that is also evident in the $\delta^{18} \mathrm{O}$ values in gastropod aragonite in paleo-lake sediments from Kotla Dahar, North India (Figure 2G) (Dixit et al., 2014a). Also the weakening in the ISM around $\sim 8.2 \mathrm{kyr}$ is visible in the biogenic carbonate $\delta^{18} \mathrm{O}$ data from another north Indian Paleolake Riwasa (Haryana, India) (Dixit et al., 2014b). Within the Holocene, two prolonged dry periods during 4.3-4.0 kyr BP and 2.0-0.6 kyr BP were observed with multiple proxy records including $\delta^{13} \mathrm{C}$ in carbonates and organic matter in the sediments from Lonar Lake, located in the core monsoon zone of central India (Figure 2H) (Prasad et al., 2014). The prolonged drought event during 4.3-4.0 kyr BP coincides with the $4.2 \mathrm{kyr}$ event. Another prolonged dry period was observed between 2 and $0.6 \mathrm{kyr} \mathrm{BP}$ in the Lonar lake records. Along with other proxy records, a decrease in the $\delta^{13} \mathrm{C}$ values in organic matter and carbonate was observed around the drought periods (Figures 2H,I) and was attributed to changes in phytoplankton metabolism from $\mathrm{CO}_{2}$ to $\mathrm{HCO}_{3}{ }^{-}$under reduced $\mathrm{CO}_{2}$ conditions. This caused enrichment in ${ }^{13} \mathrm{C}$ in organic matter and preferential degassing of ${ }^{12} \mathrm{C}$ from the supersaturated carbonates in lake water. The 




FIGURE 2 | (A) Solar insolation at $65^{\circ} \mathrm{N}$ (Laskar et al., 2006). (B) Temperature anomaly in the tropics $\left(30^{\circ} \mathrm{S}-30^{\circ} \mathrm{N}\right.$ ) (Marcott et al., 2013). (C) Mean annual rainfall in the Himalayan region (Ali et al., 2018). (D) Sahiya cave oxygen isotope record (Kathayat et al., 2017). (E) Mawmluh cave speleothem $\delta^{18} \mathrm{O}$ values from Meghalaya, NE India (Berkelhammer et al., 2012). (F) Speleothem $\delta^{18} \mathrm{O}$ values from Baratang, Andaman Islands (Laskar A. H. et al., 2013b). (G) Lake sediment biogenic carbonate and gastropod aragonite $\delta^{18} \mathrm{O}$ values from Riwasa and Kotla Dahar respectively (Dixit et al., 2014a,b). (H,I) Lonar lake $\delta^{13} \mathrm{C}$ in carbonate and organic matter (Prasad et al., 2014). (J) North Greenland lce Core $\delta^{18} \mathrm{O}$ record for the last $10 \mathrm{kyr}$ (Wolff et al., 2010). The shaded regions indicate the two global climate events around 8.2 and $4.2 \mathrm{kyr}$. The events are associated with significant changes in the ISM strengths and rise and fall of Indian ancient civilizations particularly around the $4.2 \mathrm{kyr}$ event.

$\delta^{18} \mathrm{O}$ data of North Greenland ice core (Wolff et al., 2010) are also plotted for comparison (Figure 2J) to assist in understanding the teleconnection with different proxy records from the ISM regions.
Figure 3 presents some prominent paleoclimate proxy records obtained from marine sediments from the Arabian sea and Bay of Bengal, i.e., the regions affected by ISM (see Figure 1 for locations). Oxygen isotope ratios $\left(\delta^{18} \mathrm{O}\right)$ in planktonic 


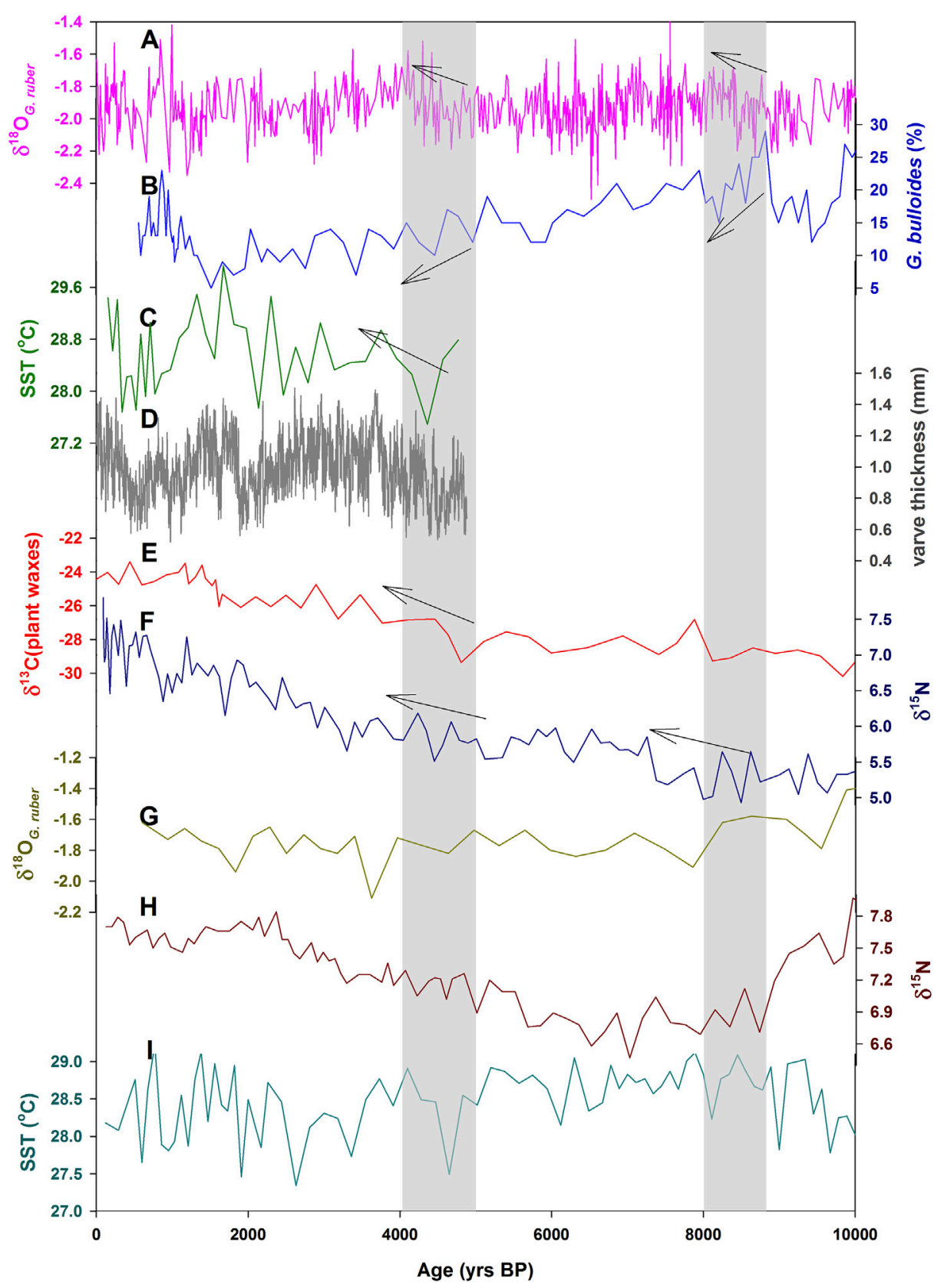

FIGURE 3 | Holocene marine proxy records from northern India ocean: (A) oxygen isotopic ratios in G. ruber from northern Arabian sea (Staubwasser et al., 2002). (B) Percentage abundance of G. bulloides from north-western Arabian sea (Gupta et al., 2003). (C) Sea surface temperature variation from Mg/Ca in the south-eastern Arabian sea (Tiwari et al., 2015). (D) Varve thickness from Northern Arabian Sea (von Rad et al., 1999). (E) Carbon isotope ratio in plant waxes from northern Bay of Bengal (Ponton et al., 2012). (F) Nitrogen isotope ratio in sediment as an indicator of denitrification and nitrous oxide emission in Arabian Sea (Pichevin et al., 2007). (G) Oxygen isotope ratio in G. ruber from Arabian Sea (Sirocko et al., 1993). (H) Nitrogen isotope ratio in sediment as an indicator of denitrification in Arabian Sea (Altabet et al., 2002). (I) Sea surface temperature reconstructed from Mg/Ca in foraminifera from south-eastern Arabian Sea (Saraswat et al., 2013). The shaded portions highlight the time periods during which the two major Holocene global climate events were reported by many researchers.

foraminifera G. ruber from the northern Arabian Sea sediment core $63 \mathrm{KA}$ for the last $10 \mathrm{kyr}$ are shown in Figure 3A (Staubwasser et al., 2002). At this location, the variations in the $\delta^{18} \mathrm{O}$ value in planktonic foraminifera depend on the Indus River discharge, and the latter is largely governed by the ISM strength. During strong ISM episodes, high discharge of the
Indus water with lower $\delta^{18} \mathrm{O}$ value drags down the $\delta^{18} \mathrm{O}$ values of the surface ocean water in the coastal region and hence the corresponding values in the planktonic foraminifera decrease. Clear increasing trends of $\delta^{18} \mathrm{O}$ values in G. ruber around 8.2 and at $4.2 \mathrm{kyr} \mathrm{BP}$ indicate weakening of ISM strength around these climate events. Figure 3B shows the foraminifer G. bulloides 
concentration variation from a sediment core recovered from an oxygen minimum zone of the continental margin of Oman in the Arabian sea. The abundance variation of G. bulloides has been linked with the variation of ISM. Its abundance is associated with the wind-driven upwelling and strong sensitivity to wind speed and monsoonal atmospheric pressure gradient making it a suitable monsoon indicator (Gupta et al., 2003). Sharply decreasing trends in the concentration of $G$. bulloides around $8.2 \mathrm{kyr}$ event indicate a weakening of the ISM. Similarly, around the $4.2 \mathrm{kyr}$ event, decreasing trend in the G. bulloides indicates a weakening of the ISM strength. These are correlated with the North Atlantic Oscillations. Mid Holocene to the recent sea surface temperature (SST) reconstructed from $\mathrm{Mg} / \mathrm{Ca}$ ratio in planktic foraminifera in the south-eastern Arabian sea is shown in Figure 3C (Tiwari et al., 2015). It is observed that the SST is significantly positively correlated with the sea surface salinity and negatively with monsoon intensity with value of coefficient of determination $\left(R^{2}\right)$ of $\sim 0.41$ for 36 data points. Stronger monsoon causes reduced salinity and SST. Increasing SST trend after $4.3 \mathrm{kyr} \mathrm{BP}$ indicates significant reduction in ISM intensity which probably coincides with the $4.2 \mathrm{kyr}$ event. ISM strength that started decreasing around $4.3 \mathrm{kyr}$ was low until $1.3 \mathrm{kyr}$ since when it increased significantly, as indicated by the SST values. Figure 3D shows the varve thickness record in a continuously laminated sediment core for the last $5 \mathrm{kyr}$ from an oxygen minimum zone of the northern Arabian sea (von Rad et al., 1999). Their varve thickness is an indicator of the Indus River discharge and hence ISM strength. Relatively low varve thickness before $4 \mathrm{kyr}$ BP indicates weak ISM around the $4.2 \mathrm{kyr}$ event. Reduced varve thickness is also observed during the Roman Warm Period ( 2 kyr BP) and Little Ice Age (0.5 kyr BP). Figure 3E shows the carbon isotopic composition $\left(\delta^{13} \mathrm{C}\right)$ in sedimentary leaf waxes in a core collected from offshore Godavari river estuary, northwestern Bay of Bengal. $\delta^{13} \mathrm{C}$ in leaf waxes is an indicator of the proportion of $\mathrm{C} 3$ and $\mathrm{C} 4$ vegetation in the Godavari River catchments (Ponton et al., 2012). A shift in the $\delta^{13} \mathrm{C}$ values after $4.5 \mathrm{kyr}$ BP indicates an increase in the proportion of $\mathrm{C} 4$ vegetation in the river catchments. $C 4$ vegetation increases with increase in aridity. Therefore, the central Indian region experienced aridity after $4 \mathrm{kyr}$ BP. Figure $\mathbf{3 F}$ shows nitrogen isotopic ratios $\left(\delta^{15} \mathrm{~N}\right)$ from the oxygen minimum zone of the Northern Arabian sea reflecting the denitrification and plant productivity in the region (Pichevin et al., 2007). Denitrification occurs under suboxic conditions and causes large nitrogen isotopic fractionation. Denitrification varies with local productivity and downward particle flux which in turn is linked to the strong summer time monsoon winds causing upwelling of the nutrient rich water in the northern Arabian sea. Therefore, under strong ISM conditions, denitrification increases, which leads to an increase in $\delta^{15} \mathrm{~N}$ values as more denitrification would enrich the remaining nitrate reservoir in ${ }^{15} \mathrm{~N}$. An increasing trend of $\delta^{15} \mathrm{~N}$ after 8.1 and $4.4 \mathrm{kyr}$ BP indicates weakening of ISM around these two climatic events. Figure 3G shows $\delta^{18} \mathrm{O}$ values of $G$. ruber from a sediment core recovered from the upwelling region of the western Arabian sea (Sirocko et al., 1993). The change in the foraminiferal $\delta^{18} \mathrm{O}$ is attributed to the change in ISM. A shift towards lower $\delta^{18} \mathrm{O}$ values can be due to one or more of the following reasons: an increase in precipitation or decrease in evaporation, an increase in the proportion of Gulf outflow water with relatively lower $\delta^{18} \mathrm{O}$ values, a change in the seasonal growth of the G. ruber species, or an increase in the SST (Sirocko et al., 1993). Relatively higher $\delta^{18} \mathrm{O}$ values around $8.2 \mathrm{kyr}$ probably indicated weaker ISM precipitation though the other factors mentioned above can also be partly responsible for the increased $\delta^{18} \mathrm{O}$ values. However, the change around the $4.2 \mathrm{kyr}$ event is not obvious in this sediment isotope record probably due to coarser time resolution. Figure $\mathbf{3 H}$ shows $\delta^{15} \mathrm{~N}$ values in a sediment core recovered from the Oman continental margin of the Arabian Sea reflecting the denitrification and productivity in the region. As mentioned before, denitrification in Arabian sea is controlled by ISM strength. For the period of last $10 \mathrm{kyr}$, weaker ISM was observed during 8.7-5.7 kyr BP indicated by low $\delta^{15} \mathrm{~N}$ values. The $\delta^{15} \mathrm{~N}$ values started increasing from $5.7 \mathrm{kyr}$ BP indicating strengthening of ISM. Figure 3G shows centennial scale SST reconstructed from foraminiferal $\mathrm{Mg} / \mathrm{Ca}$ ratio in a sediment core from south-eastern Arabian Sea. However, the sharp Holocene climatic events such as those observed around 8.2 and $4.2 \mathrm{kyr}$ BP are not very clear in this sediment record probably because of its relatively coarser time resolution and core location.

A number of global climate events influenced the Holocene ISM rainfall including the two major events around 8.2 and $4.2 \mathrm{kyr} \mathrm{BP}$ and are evident in most of the terrestrial and oceanic proxy climate records. The changes in the proxy records in the terrestrial archives are larger in magnitude due to direct influence from ISM rainfall, and the signals are dampened in the oceanic reservoir due to its large size and slow response. It is to be noted that the two climatic events are not obvious in all the climate proxy records obtained in different geographical locations and, as mentioned before, there are differences in the timing of the events indicating spatial variation of the influences of ISM. We also note that there are climatic events comparable to the 8.2 or $4.2 \mathrm{kyr} \mathrm{BP}$ in some of the proxy records but not highlighted as much as these two events. Probably those events were confined to regional scale and are not reflected at global scale. It is also important to address how these local climate events influenced the human settlements. This needs further focused studies with better constrained chronology, wider geographic distribution, and quantitative analysis. Some possibilities for quantitative studies are discussed below.

\section{OUTLOOK}

There are two important aspects that need to be addressed to better understand the timing and causes of falls of ancient Indian civilizations. First, more archaeological data from the existing and new archaeological sites are required for understanding the timing of evolution of various civilizations and their terminations. There are many unexplored archaeological sites in the subcontinent and they can be used for this purpose though the majority are 
not easily accessible for political reasons. Second, more focused studies on quantitative estimates of the changes in climate parameters such as temperature and rainfall that favored/disfavored the ancient settlers with better chronological constraints are required. Most of the available studies used strengthening/weakening of the Indian Summer Monsoon qualitatively. It is important to obtain quantitative estimates of the extent of increase/decrease of the monsoon strengths at different ancient periods that are societally relevant. This would help to better manage future climate catastrophes. The role of change in air temperature might have influences on human settlements as well. It is important to see if prolonged drought periods were associated with any increase in regional air temperatures significantly. Tree ring is one of the best terrestrial paleoclimate records and can improve our understanding of the past monsoon and temperature variation. Unfortunately, the available dendroclimatology studies from India and surrounding regions do not cover the time periods of most of the ancient civilizations (Yadav, 2009; Yadav, 2013). With tree ring data covering the periods of interest, it is probably possible to better understand the monsoon variability at higher temporal resolutions.

Many of the aforementioned proxy records are controlled by combined influences of rainfall, evaporation, and temperature (e.g., $\delta^{18} \mathrm{O}$ in speleothems, foraminifera, and lake sediment carbonates), and it is difficult to disentangle the signatures. For example, tropical speleothem $\delta^{18} \mathrm{O}$ values are interpreted based on amount effect in many studies (Yadava and Ramesh, 2005; Laskar A. H. et al., 2013b), but this effect is absent or feeble in many ISM dominated regions (Laskar et al., 2015; Lekshmy et al., 2014). Even in the regions influenced by the amount effect, the rainfall variation explains the $\delta^{18} \mathrm{O}$ variability partially making it difficult for a quantitative reconstruction of past rainfall. Therefore, it is important to look into new experimental and modelling techniques for quantitative reconstruction of paleomonsoon and temperature. Carbonate clumped isotope thermometry (e.g., Ghosh et al., 2006; Laskar et al., 2016) has the potential to independently constrain the temperature and can be combined with conventional oxygen isotope ratios to quantitatively estimate the rainfall variation in some paleoarchives. However, the thermometer has not been successfully applied to reconstruct temperatures from cave carbonates, but it has potentials in sediment carbonates (e.g., Quade et al., 2013; Beverly et al., 2021). With the advances of techniques, it is possible to constrain the absolute changes in temperature to a precision of $1-2^{\circ} \mathrm{C}$ (Thiagarajan et al., 2014; Tripati et al., 2014). Once temperature is constrained, the changes in the $\delta^{18} \mathrm{O}$ values probably would help to quantitatively estimate the changes in the rainfall. Another recently developed proxy is the triple oxygen isotopic composition which can also be applied in carbonate archives (Passey et al., 2014; Sha et al., 2020). It depends on the extent of kinetic isotopic fractionation during carbonate precipitation, which in turn depends on the ambient relative humidity. The new experimental measurements can be combined with model data to quantitatively reconstruct the past rainfall and temperature variation.

\section{SUMMARY}

We have discussed the cultural shifts in the Indian subcontinent and reviewed some important marine and terrestrial climate data for the last $10 \mathrm{kyr}$ from the ISM dominated regions to understand the role of monsoon on rise and collapse of the ancient Indian civilizations. The human settlement and agricultural activity in Indian subcontinent probably started around $9 \mathrm{kyr} \mathrm{BP}$ as evident from multiple archaeological findings. The two major climate events at $8.2 \mathrm{kyr}$ and $4.2 \mathrm{kyr} \mathrm{BP}$ are evident in most of the climate proxies. Though the $8.2 \mathrm{kyr}$ event influenced the ISM significantly, but its role on the civilization is not obvious mainly due to lack of early Holocene archaeological data in the Indian subcontinent. The collapse of the Harappan Civilization was probably due to the weakening of the Indian Summer Monsoon after $4.2 \mathrm{kyr}$ BP as indicated by many climate proxies. We observed that most of the available paleoclimate records discussed the monsoon rainfall change qualitatively. It is extremely important to quantitatively obtain estimates of the various climate parameters including change in rainfall and temperature that probably caused the collapse of the civilizations. Some recently established paleoclimate proxies such as carbonate clumped isotope thermometry along with conventional oxygen isotope ratios in carbonate archives can probably disentangle the temperature and rainfall signature and help to estimate the rainfall variation quantitatively. Further combined analysis of multiple proxies in high resolution paleoclimate archives, precise dates of diverse archaeological samples, and more extensive paleoclimate model studies may help enhance our understanding of the rise, evolution, and collapse of early human civilizations and impacts of climate change on them.

\section{DATA AVAILABILITY STATEMENT}

The data reviewed in the present study are available with the original publications and are cited at the appropriate places of the article; further inquiries can be directed to the corresponding author.

\section{AUTHOR CONTRIBUTIONS}

AL formulated the study and wrote the manuscript in discussion with $\mathrm{AB}$. $\mathrm{AB}$ reviewed the manuscript.

\section{ACKNOWLEDGMENTS}

The authors thank the Director of the Physical Research Laboratory for his support and encouragement to conduct the present study. AHL thanks Dr. Anoop Ambili for inviting him to contribute to this article. $\mathrm{AB}$ acknowledges CSIR for funding through SRA fellowship (13(9024-A)/2019. POOL). 


\section{REFERENCES}

Ali, S. N., Dubey, J., Ghosh, R., Quamar, M. F., Sharma, A., Morthekai, P., et al. (2018). High Frequency Abrupt Shifts in the Indian Summer Monsoon since Younger Dryas in the Himalaya. Sci. Rep. 8, 9287. doi:10.1038/s41598-01827597-6

Altabet, M. A., Higginson, M. J., and Murray, D. W. (2002). The Effect of Millennial-Scale Changes in Arabian Sea Denitrification on Atmospheric CO2. Nature 415, 159-162. doi:10.1038/415159a

Atkins, P. J., Simmons, I., and Roberts, B. K. (1998). "Environmental Degradation and the Collapse of Civilizations," in People, Land and Time: An Historical Introduction to the Relations between Landscape, Culture and Environment. Editors P. Atkins, I. Simmons, and B. Roberts (New York and London: Routledge, Taylor and Fransis Group).

Balter, M. (2010). In a Cold Snap, Farmers Turned to Milk. Science 329 (5998), 1465. doi:10.1126/science.329.5998.1465

Band, S., Yadava, M. G., Lone, M. A., Shen, C.-C., Sree, K., and Ramesh, R. (2018). High-resolution Mid-holocene Indian Summer Monsoon Recorded in a Stalagmite from the Kotumsar Cave, Central India. Quat. Int. 479, 19-24. doi:10.1016/j.quaint.2018.01.026

Banerji, U. S., Arulbalaji, P., and Padmalal, D. (2020). Holocene Climate Variability and Indian Summer Monsoon: An Overview. The Holocene 30 (5), 744-773. doi:10.1177/0959683619895577

Barber, D. C., Dyke, A., Hillaire-Marcel, C., Jennings, A. E., Andrews, J. T., Kerwin, M. W., et al. (1999). Forcing of the Cold Event of 8,200 Years Ago by Catastrophic Drainage of Laurentide Lakes. Nature 400 (6742), 344-348. doi:10.1038/22504

BarkerRichards, G. M. B., and Richards, M. B. (2013). Foraging-Farming Transitions in Island Southeast Asia. J. Archaeol. Method Theor. 20, 256-280. doi:10.1007/s10816-012-9150-7

Basu, S., Agrawal, S., Sanyal, P., Mahato, P., Kumar, S., and Sarkar, A. (2015). Carbon Isotopic Ratios of Modern C3-C4 Plants from the Gangetic Plain, India and its Implications to Paleovegetational Reconstruction. Palaeogeogr. Palaeoclimatol. Palaeoecol. 440, 22-32. doi:10.1016/j.palaeo.2015.08.012

Bauer, E., Ganopolski, A., and Montoya, M. (2004). Simulation of the Cold Climate Event 8200 Years Ago by Meltwater Outburst from Lake Agassiz. Paleoceanogr. Paleoclim. 19 (3), 001030. doi:10.1029/2004pa001030

Berger, J.-F., and Guilaine, J. (2009). The 8200calBP Abrupt Environmental Change and the Neolithic Transition: A Mediterranean Perspective. Quat. Int. 200, 31-49. doi:10.1016/j.quaint.2008.05.013

Berkelhammer, M., Sinha, A., Mudelsee, M., Cheng, H., Edwards, R. L., and Cannariato, K. (2010). Persistent Multidecadal Power of the Indian Summer Monsoon. Earth Planet. Sci. Lett. 290, 166-172. doi:10.1016/j.epsl.2009.12.017

Berkelhammer, M., Sinha, A., Stott, L., Cheng, H., Pausata, F., and Yoshimura, K. (2012). An Abrupt Shift in the Indian Monsoon 4000 Years Ago. Geophys. Monogr. Ser. 198, 75-88.

Beverly, E. J., Levin, N. E., Passey, B. H., Aron, P. G., Yarian, D. A., Page, M., et al. (2021). Triple Oxygen and Clumped Isotopes in Modern Soil Carbonate along an Aridity Gradient in the Serengeti, Tanzania. Earth Planet. Sci. Lett. 567, 116952. doi:10.1016/j.epsl.2021.116952

Buckley, B. M., Anchukaitis, K. J., Penny, D., Fletcher, R., Cook, E. R., Sano, M., et al. (2010). Climate as a Contributing Factor in the Demise of Angkor, Cambodia. Proc. Natl. Acad. Sci. 107, 6748-6752. doi:10.1073/pnas.0910827107

Budja, M. (2007). The 8200 calBP 'climate Event' and the Process of Neolithisation in South-Eastern Europe. Doc. Praeh. 34, 191-201. doi:10.4312/dp.34.14

Butzer, K. W. (2012). Collapse, Environment, and Society. Proc. Natl. Acad. Sci. 109, 3632-3639. doi:10.1073/pnas.1114845109

Cai, Y., Zhang, H., Cheng, H., An, Z., Lawrence Edwards, R., Wang, X., et al. (2012). The Holocene Indian Monsoon Variability over the Southern Tibetan Plateau and its Teleconnections. Earth Planet. Sci. Lett. 335-336, 135-144. doi:10.1016/ j.epsl.2012.04.035

Chatterjee, A., Ray, J. S., Shukla, A. D., and Pande, K. (2019). On the Existence of a Perennial River in the Harappan Heartland. Sci. Rep. 9, 17221. doi:10.1038/ s41598-019-53489-4

Chauhan, D. S. (1999). "Mythological Observations and Scientific Evaluation of the Lost Sarasvati River,". Vedic Sarasvati. Editors B. P. Radhakrishna and S. S. Merh (Bangalore, India: Memoir Geol. Soc. India), 42, 35-45.
Cheng, H., Fleitmann, D., Edwards, R. L., Wang, X., Cruz, F. W., Auler, A. S., et al (2009). Timing and Structure of the $8.2 \mathrm{Kyr}$ B.P. Event Inferred from $\delta 18 \mathrm{O}$ Records of Stalagmites from China, Oman, and Brazil. Geology 37 (11), 1007-1010. doi:10.1130/g30126a.1

Cook, E. R., Anchukaitis, K. J., Buckley, B. M., D’Arrigo, R. D., Jacoby, G. C., and Wright, W. E. (2010). Asian Monsoon Failure and Megadrought during the Last Millennium. Science 328 (5977), 486-489. doi:10.1126/science.1185188

Cullen, H. M., deMenocal, P. B., Hemming, S., Hemming, G., Brown, F. H., Guilderson, T., et al. (2000). Climate Change and the Collapse of the Akkadian empire: Evidence from the Deep Sea. Geology 28, 379-382. doi:10.1130/00917613(2000)028<0379:ccatco $>2.3 . c 0 ; 2$

Di Rita, F., and Magri, D. (2009). Holocene Drought, Deforestation and evergreen Vegetation Development in the central Mediterranean: a 5500 Year Record from Lago Alimini Piccolo, Apulia, Southeast Italy. The Holocene 19, 295-306. doi:10.1177/0959683608100574

Dixit, Y., Hodell, D. A., and Petrie, C. A. (2014a). Abrupt Weakening of the Summer Monsoon in Northwest India 4100 Yr Ago. Geology 42 (4), 339-342. doi:10.1130/g35236.1

Dixit, Y., Hodell, D. A., SinhaPetrie, R. C. A., and Petrie, C. A. (2014b). Abrupt Weakening of the Indian Summer Monsoon at 8.2 Kyr B.P. Earth Planet. Sci. Lett. 391, 16-23. doi:10.1016/j.epsl.2014.01.026

Dixit, Y., and Tandon, S. K. (2016). Hydroclimatic Variability on the Indian Subcontinent in the Past Millennium: Review and Assessment. Earth-Science Rev. 161, 1-15. doi:10.1016/j.earscirev.2016.08.001

Dobhal, D. P., Gupta, A. K., Mehta, M., and Khandelwal, D. D. (2013). Kedarnath Disaster: Facts and Plausible Causes. Curr. Sci. 105 (2), 171-174.

Drysdale, R., Zanchetta, G., Hellstrom, J., Maas, R., Fallick, A., Pickett, M., et al. (2006). Late Holocene Drought Responsible for the Collapse of Old World Civilizations Is Recorded in an Italian Cave Flowstone. Geol 34, 101-104. doi:10.1130/g22103.1

Dutt, S., Gupta, A. K., Clemens, S. C., Cheng, H., Singh, R. K., Kathayat, G., et al. (2015). Abrupt Changes in Indian Summer Monsoon Strength during 33,800 to 5500 Years B.P. Geophys. Res. Lett. 42 (13), 5526-5532. doi:10.1002/ 2015gl064015

Dutt, S., Gupta, A. K., Singh, M., Jaglan, S., Saravanan, P., Balachandiran, P., et al. (2019). Climate Variability and Evolution of the Indus Civilization. Quat. Int. 507, 15-23. doi:10.1016/j.quaint.2018.11.012

Dutt, S., Gupta, A. K., Wünnemann, B., and Yan, D. (2018). A Long Arid Interlude in the Indian Summer Monsoon during 4,350 to 3,450 Cal. Yr BP Contemporaneous to Displacement of the Indus valley Civilization. Quat. Int. 482, 83-92. doi:10.1016/j.quaint.2018.04.005

Enzel, Y., Ely, L. L., Mishra, S., Amit, R., Ramesh, R., Lazar, B., et al. (1999). HighResolution Holocene Environmental Changes in the Thar Desert, Northwestern India. Science 284 (5411), 125-128. doi:10.1126/ science.284.5411.125

Fairservis, W. A. (1967). The Origins, Character and Decline of an Early Civilization. Am. Mus. Novit. 2302, 1-48.

Finné, M., Holmgren, K., Shen, C. C., Hu, H.-M., Boyd, M., and Stocker, S. (2017). Late Bronze Age Climate Change and Descrution of the Mycenaean Palace of Nestor at Pylos. PLoS ONE 12, e0189447. doi:10.1371/journal.pone.0189447

Finné, M., Holmgren, K., Sundqvist, H. S., Weiberg, E., and Lindblom, M. (2011). Climate in the Eastern Mediterranean, and Adjacent Regions, during the Past 6000 Years - A Review. J. Archaeological Sci. 38, 3153-3173. doi:10.1016/ j.jas.2011.05.007

Fitzsimons, M. A. (1970). The Indus Valley Civilization. Hist. Teach. 4 (1), 9-22. doi: $10.2307 / 492135$

Fleitmann, D., Burns, S. J., Mangini, A., Mudelsee, M., Kramers, J., Villa, I., et al. (2007). Holocene ITCZ and Indian Monsoon Dynamics Recorded in Stalagmites from Oman and Yemen (Socotra). Quat. Sci. Rev. 26 (1), 170-188. doi:10.1016/j.quascirev.2006.04.012

Fleitmann, D., Burns, S. J., Mudelsee, M., Neff, U., Kramers, J., Mangini, A., et al. (2003). Holocene Forcing of the Indian Monsoon Recorded in a Stalagmite from Southern Oman. Science 300, 1737-1739. doi:10.1126/science.1083130

Fuller, D. Q., and Madella, M. (2002). Indian Archaeology in Retrospect. Protohistory. Editors S. Settar and R. Korisettar (New Delhi: Manohar Publishers), Vol. II, 317-390.

Gadgil, S., and Gadgil, S. (2006). The Indian Monsoon, GDP and Agriculture. Econ. Polit. Weekly XLI (47), 4887-4895. 
Gadgil, S. (2018). The Monsoon System: Land-Sea Breeze or the ITCZ? J. Earth Syst. Sci. 127 (1). doi:10.1007/s12040-017-0916-x

Gangal, K., Vahia, M., and Adhikari, R. (2010). Spatio-temporal Analysis of the Indus Urbanization. Curr. Sci 98, 846-852.

Ghosh, P., Adkins, J., Affek, H., Balta, B., Guo, W., Schauble, E. A., et al. (2006). 13C-18O Bonds in Carbonate Minerals: A New Kind of Paleothermometer. Geochimica et Cosmochimica Acta 70, 1439-1456. doi:10.1016/ j.gca.2005.11.014

Giosan, L., Clift, P. D., Macklin, M. G., Fuller, D. Q., Constantinescu, S., Durcan, J. A., et al. (2012). Fluvial Landscapes of the Harappan Civilization. Proc. Natl. Acad. Sci. 109 (26), E1688-E1694. doi:10.1073/pnas.1112743109

Goswami, B. N., Madhusoodanan, M. S., Neema, C. P., and Sengupta, D. (2006). A Physical Mechanism for North Atlantic SST Influence on the Indian Summer Monsoon. Geophys. Res. Lett. 33 (2), 024803. doi:10.1029/2005gl024803

Green, A. S. (2021). Killing the Priest-King: Addressing Egalitarianism in the Indus Civilization. J. Archaeol Res. 29, 153-202. doi:10.1007/s10814-020-09147-9

Gronenborn, D. (2009). Climate Fluctuations and Trajectories to Complexity in the Neolithic: towards a Theoryfluctuations and Trajectories to Complexity in the Neolithic: towards a Theory. Doc. Praeh. 36, 97-110. doi:10.4312/dp.36.5

Gupta, A. K., Anderson, D. M., and Overpeck, J. T. (2003). Abrupt Changes in the Asian Southwest Monsoon during the Holocene and Their Links to the North Atlantic Ocean. Nature 421, 354-357. doi:10.1038/nature01340

Gupta, A. K., Dutt, S., Cheng, H., and Singh, R. K. (2020). Abrupt Changes in Indian Summer Monsoon Strength during the Last $\sim 900$ years and Their Linkages to Socio-Economic Conditions in the Indian Subcontinent. Palaeogeogr. Palaeoclimatol. Palaeoecol. 536, 109347.

Gupta, V. (2004). Global Climate Change: India's Local Concerns. Ier 6 (1), 54-59. doi:10.1504/ier.2004.053917

IPCC AR5 (2013). Climate Change 2013: The Physical Science Basis.

Jacobsen, T., and Adams, R. M. (1958). Salt and Silt in Ancient Mesopotamian Agriculture: Progressive Changes in Soil Salinity and Sedimentation Contributed to the Breakup of Past Civilizations. Science 128 (3334), 1251-1258. doi:10.1126/science.128.3334.1251

Jarrige, J. F. (1981). "Chronology of the Earlier Periods of the Greater Indus as Seen from Mehrgarh, Pakistan," in South Asian Archaeology 1981. Editor B. Allchin (Cambridge: Cambridge University Press).

Jarrige, J. F., and Lechevallier, M. (1979). "Excavations at Mehrgarh, Baluchistan," in South Asian Archaeology 1977. Insti-tuto Universitario Orientale, Naples. Editor M. Taddei.

Jarrige, J. F. (1993). The Early Architectural Traditions of Greater Indus as Seen from Mehrgarh, Baluchistan. New England: University Press of.

Kaniewski, D., Van Campo, E., Morhange, C., Guiot, J., Zviely, D., Shaked, I., et al. (2013). Early Urban Impact on Mediterranean Coastal Environments. Sci. Rep. 3, 3540. doi:10.1038/srep03540

Kathayat, G., Cheng, H., Sinha, A., Berkelhammer, M., Zhang, H., Duan, P., et al. (2018). Evaluating the Timing and Structure of the $4.2 \mathrm{Ka}$ Event in the Indian Summer Monsoon Domain from an Annually Resolved Speleothem Record from Northeast India. Clim. Past 14 (12), 1869-1879. doi:10.5194/cp-14-1869-2018

Kathayat, G., Cheng, H., Sinha, A., Spötl, C., Edwards, R. L., Zhang, H., et al. (2016). Indian Monsoon Variability on Millennial-Orbital Timescales. Sci. Rep. 6, 24374. doi:10.1038/srep24374

Kathayat, G., Cheng, H., Sinha, A., Yi, L., Li, X., Zhang, H., et al. (2017). The Indian Monsoon Variability and Civilization Changes in the Indian Subcontinent. Sci. Adv. 3 (12), e1701296. doi:10.1126/sciadv.1701296

Kenoyer, J. M. (2006). in Historical Roots in the Making of 'the Aryan'. Editor R. Thapar (New Delhi: National Book Trust).

Kenoyer, J. M. (1998). Ancient Cities of the Indus Valley Civilization. Oxford: Oxford University Press.

Kenoyer, J. M. (1997). Trade and Technology of the Indus valley: New Insights from Harappa, Pakistan. World Archaeology 29 (2), 262-280. doi:10.1080/ 00438243.1997.9980377

Kidder, T., Liu, H., Xu, Q., and Li, M. (2012). The Alluvial Geoarchaeology of the Sanyangzhuang Site on the Yellow River Floodplain, Henan Province, China. Geoarchaeology 27, 324-343. doi:10.1002/gea.21411

Kobashi, T., Severinghaus, J. P., Brook, E. J., Barnola, J.-M., and Grachev, A. M. (2007). Precise Timing and Characterization of Abrupt Climate Change 8200 Years Ago from Air Trapped in Polar Ice. Quat. Sci. Rev. 26, 1212-1222. doi:10.1016/j.quascirev.2007.01.009
Kohn, M. J. (2010). Carbon Isotope Compositions of Terrestrial C3 Plants as Indicators of (Paleo)ecology and (Paleo)climate. Proc. Natl. Acad. Sci. 107, 19691-19695. doi:10.1073/pnas.1004933107

Korisettar, R., Venkatasubbaiah, P. C., and Fuller, D. Q. (2002). "Brahmagiri and beyond: the Archaeology of the Southern Neolithic,". Indian Archaeology in Retrospect: Prehistory. Editors S. Settar and R. Korisettar (New Delhi: Indian Council of Historical Research and Manohar Publishers), Vol. 1, 150-237.

Kotlia, B. S., Singh, A. K., Joshi, L. M., and Bisht, K. (2018). Precipitation Variability over Northwest Himalaya from 4.0 to $1.9 \mathrm{Ka}$ BP with Likely Impact on Civilization in the Foreland Areas. J. Asian Earth Sci. 162, 148-159. doi:10.1016/j.jseaes.2017.11.025

Kotlia, B. S., Singh, A. K., Zhao, J.-X., Duan, W., Tan, M., Sharma, A. K., et al. (2017). Stalagmite Based High Resolution Precipitation Variability for Past Four Centuries in the Indian Central Himalaya: Chulerasim Cave Re-visited and Data Re-interpretation. Quat. Int. 444, 35-43. doi:10.1016/ i.quaint.2016.04.007

Kulke, H., and Rothermund, D. (2004). A History of India. fourth Edition. London and New York: Routledge Taylor and Francis Group.

Kumar, K. K., Rajagopalan, B., Hoerling, M., Bates, G., and Cane, M. (2006). Unraveling the Mystery of Indian Monsoon Failure during El Nino. Science 314, 115-119. doi:10.1126/science.1131152

Kumar, M. (2009). in Linguistics, Archaeology and the Human Past, Occasional Paper 7. Research Institute for Humanity and Nature. Editors T. Osada and A. Uesugi (Kyoto): Nakanishi Printing Co. Ltd), 1-75.

Laskar, A. H., Ramesh, R., Burman, J., Midhun, M., Jani, R. A., Yadva, M. G., et al. (2015). Stable Water Isotopic Characterization in Nor'westers in the South Assam, Northeast India. J. Clim. Change 1 (1-2), 75-87. doi:10.3233/jcc-150006

Laskar, A. H., Sharma, N., Ramesh, R., Jani, R. A., and Yadava, M. G. (2010). Paleoclimate and Paleovegetation of Lower Narmada Basin, Gujarat, Western India, Inferred from Stable Carbon and Oxygen Isotopes. Quat. Int. 227, 183-189. doi:10.1016/j.quaint.2010.05.020

Laskar, A., Yadava, M., Sharma, N., and Ramesh, R. (2013a). Late-Holocene Climate in the Lower Narmada valley, Gujarat, Western India, Inferred Using Sedimentary Carbon and Oxygen Isotope Ratios. The Holocene 23 (8), 1115-1122. doi:10.1177/0959683613483621

Laskar, A. H., Yadava, M. G., Ramesh, R., Polyak, V. J., and Asmerom, Y. (2013b). A 4 Kyr Stalagmite Oxygen Isotopic Record of the Past Indian Summer Monsoon in the Andaman Islands. Geochem. Geophys. Geosyst. 14 (9), 3555-3566. doi:10.1002/ggge.20203

Laskar, A. H., Yui, T.-F., and Liang, M.-C. (2016). Clumped Isotope Composition of Marbles from the Backbone Range of Taiwan. Terra Nova 28 (4), 265-270. doi:10.1111/ter.12217

Laskar, J., Robutel, P., Joutel, F., Gastineau, M., Correia, A. C. M., and Levrard, B. (2006). Long-term Solution for the Insolation Quantities of the Earth. Proc. IAU 2 (14), 465. doi:10.1017/s1743921307011404

Lawler, A. (2008). UNMASKING the INDUS: Trench Warfare: Modern Borders Split the Indus. Science 320, 1282-1283. doi:10.1126/science.320.5881.1282

Lekshmy, P. R., Midhun, M., Ramesh, R., Jani, R. A., et al. (2014). 180 Depletion in Monsoon Rain Relates to Large Scale Organized Convection Rather than the Amount of Rainfall. Sci. Rep. 4, 5661. doi:10.1038/srep05661

Liang, F., Brook, G. A., Kotlia, B. S., Railsback, L. B., Hardt, B., Cheng, H., et al. (2015). Panigarh Cave stalagmite Evidence of Climate Change in the Indian Central Himalaya since AD 1256: Monsoon Breaks and Winter Southern Jet Depressions. Quat. Sci. Rev. 124, 145-161. doi:10.1016/ j.quascirev.2015.07.017

Liu, F., and Feng, Z. (2012). A Dramatic Climatic Transition at 4000 Cal. Yr BP and its Cultural Responses in Chinese Cultural Domains. The Holocene 22 (10), 1181-1197. doi:10.1177/0959683612441839

Liu, Y.-H., Henderson, G. M., Hu, C.-Y., Mason, A. J., Charnley, N., Johnson, K. R., et al. (2013). Links between the East Asian Monsoon and North Atlantic Climate during the 8,200 Year Event. Nat. Geosci 6, 117-120. doi:10.1038/ ngeo1708

MacDonald, G. (2011). Potential Influence of the Pacific Ocean on the Indian Summer Monsoon and Harappan Decline. Quat. Int. 229, 140-148. doi:10.1016/j.quaint.2009.11.012

Macklin, M. G., and Lewin, J. (2015). The Rivers of Civilization. Quat. Sci. Rev. 114 228-244. doi:10.1016/j.quascirev.2015.02.004 
Macklin, M. G., Woodward, J. C., Welsby, D. A., Duller, G. A. T., Williams, F. M., and Williams, M. A. J. (2013). Reach-scale River Dynamics Moderate the Impact of Rapid Holocene Climate Change on Floodwater Farming in the Desert Nile. Geology 41 (6), 695-698. doi:10.1130/g34037.1

Madella, M., and Fuller, D. Q. (2006). Palaeoecology and the Harappan Civilisation of South Asia: a Reconsideration. Quat. Sci. Rev. 25, 1283-1301. doi:10.1016/ j.quascirev.2005.10.012

Magny, M., Vanniere, B., Zanchetta, G., Fouache, E., Touchias, G., Petrika, L., et al. (2009). Possible Complexity of the Climatic Event Around 4300-3800 Cal. BP in the central and Western Mediterranean. The Holocene 19, 1-11. doi:10.1177/ 0959683609337360

Magri, D., and Parra, I. (2002). Late Quaternary Western Mediterranean Pollen Records and African Winds. Earth Planet. Sci. Lett. 200, 401-408. doi:10.1016/ s0012-821x(02)00619-2

Marcott, S. A., Shakun, J. D., Clark, P. U., and Mix, A. C. (2013). A Reconstruction of Regional and Global Temperature for the Past 11,300 Years. Science 339, 1198-1201. doi:10.1126/science.1228026

Margaritelli, G., Vallefuoco, M., Di Rita, F., Capotondi, L., Bellucci, L. G., Insinga, D., et al. (2016). Marine response to climate changes during the last five millennia in the central Mediterranean Sea. Global Planet. Change 142, 53-72.

Mayewski, P. A., Rohling, E. E., Curt Stager, J., Karlén, W., Maasch, K. A., Meeker, L. D., et al. (2004). Holocene Climate Variability. Quat. Res. 62 (3), 243-255. doi:10.1016/j.yqres.2004.07.001

Mehrotra, N., Shah, S. K., Basavaiah, N., Laskar, A. H., Yadava, M. G., and Yadava, M. G. (2019). Resonance of the '4.2ka Event' and Terminations of Global Civilizations during the Holocene, in the Palaeoclimate Records Around PT Tso Lake, Eastern Himalaya. Quat. Int. 507, 206-216. doi:10.1016/j.quaint.2018.09.027

Migowski, C., Stein, M., Prasad, S., Negendank, J. F. W., and Agnon, A. (2006). Holocene Climate Variability and Cultural Evolution in the Near East from the Dead Sea Sedimentary Record. Quat. Res. 66, 421-431. doi:10.1016/ j.yqres.2006.06.010

Mughal, M. R. (1997). Ancient Cholistan: Archaeology and Architecture. Lahore: Ferozsons.

Nakamura, A., Yokoyama, Y., Maemoku, H., Yagi, H., Okamura, M., Matsuoka, H., et al. (2016). Weak Monsoon Event at 4.2 ka Recorded in Sediment From Lake Rara, Himalayas. Quat. Int. 397, 349-359. doi:10.1016/j.quaint.2015.05.053

Paliwal, B. S. (2011). Abrupt Holocene Climatic Change in Northwestern India: Disappearance of the Sarasvati River and the End of Vedic Civilization. Geophys. Monogr. Ser. 193, 185-194. doi:10.1029/2010GM001028

P. A. McAnany and N. Yoffee (Editors) (2010) Questioning Collapse: Human Resilience, Ecological Vulnerability, and the Aftermath of Empire (Cambridge: Cambridge University Press).

Panja, S. (2002). "Research on the Deccan Chalcolithic,". Indian Archaeology in Retrospect: Prehistory. Editors S. Settar and R. Korisettar (New Delhi: Indian Council of Historical Research and Manohar Publishers), Vol. 1, 263-276.

Passey, B. H., Hu, H., Ji, H., Montanari, S., Li, S., Henkes, G. A., et al. (2014). Triple Oxygen Isotopes in Biogenic and Sedimentary Carbonates. Geochimica et Cosmochimica Acta 141, 1-25. doi:10.1016/j.gca.2014.06.006

Petrie, C. A., Singh, R. N., Bates, J., Dixit, Y., French, C. A. I., Hodell, D. A., et al. (2017). Adaptation to Variable Environments, Resilience to Climate Change: InvestigatingLand, Water and Settlementin Indus Northwest India. Curr. Anthropol. 58, 1-30. doi:10.1086/690112

Phadtare, N. R. (2000). Sharp Decrease in Summer Monsoon Strength 4000-3500 Cal Yr B.P. In the Central Higher Himalaya of India Based on Pollen Evidence from Alpine Peat. Quat. Res. 53, 122-129. doi:10.1006/qres.1999.2108

Pichevin, L., Bard, E., Martinez, P., and Billy, I. (2007). Evidence of Ventilation Changes in the Arabian Sea during the Late Quaternary: Implication for Denitrification and Nitrous Oxide Emission. Glob. Biogeochem. Cycles 21, GB4008. doi:10.1029/2006gb002852

Pokharia, A. K., Kharakwal, J. S., and Srivastava, A. (2014). Archaeobotanical evidence of millets in the Indian subcontinent with some observations on their role in the Indus civilization. Journal of Archaeological Science 42, 442-455.

Ponton, C., Giosan, L., EglintonFuller, T. I. D. Q., Johnson, J. E., Kumar, P., and Collett, T. S. (2012). Holocene Aridification of India. Geophys. Res. Lett. 39 (3), 050722. doi:10.1029/2011gl050722

Possehl, G. L. (2002a). The Indus Civilization: A Contemporary Perspective. Oxford: Rowman \& Littlefield Publishers, Inc.
Possehl, G. L. (2002b). The Indus Civilization: A Contemporary Perspective. Altamira Press.

Prasad, S., Anoop, A., Riedel, N., Sarkar, S., Menzel, P., Basavaiah, N., et al. (2014). Prolonged Monsoon Droughts and Links to Indo-Pacific Warm Pool: A Holocene Record from Lonar Lake, central Indiac Warm Pool: A Holocene Record from Lonar Lake, central India. Earth Planet. Sci. Lett. 391, 171-182. doi:10.1016/j.epsl.2014.01.043

Pruti, R. K. (2004). Culture and Civilization Series Vedic Civilization. New Delhi: Discovery Publishing House.

Quade, J., Eiler, J., Daëron, M., and Achyuthan, H. (2013). The Clumped Isotope Geothermometer in Soil and Paleosol Carbonate. Geochimica et Cosmochimica Acta 105, 92-107. doi:10.1016/j.gca.2012.11.031

Radhakrishna, B. P., and Merh, S. S. (1999). Vedic Saraswati. Memoir. Geol. Soc. India 42.

Railsback, L. B., Liang, F., Brook, G. A., Voarintsoa, N. R. G., Sletten, H. R., Marais, E., et al. (2018). The Timing, Two-Pulsed Nature, and Variable Climatic Expression of the 4.2 Ka Event: A Review and New High-Resolution Stalagmite Data from Namibia. Quat. Sci. Rev. 186, 78-90. doi:10.1016/j.quascirev.2018.02.015

Ramsey, C. B., Dee, M. W., Rowland, J. M., Higham, T. F. G., Harris, S. A., Brock, F., et al. (2010). Radiocarbon-Based Chronology for Dynastic Egypt. Science 328, 1554-1557. doi:10.1126/science.1189395

Rana, N., Sharma, S., Sundriyal, Y., Kaushik, S., Pradhan, S., Tiwari, G., et al. (2021). A Preliminary Assessment of the 7th February 2021 Flashflood in Lower Dhauli Ganga valley, Central Himalaya, India. J. Earth Syst. Sci. 130, 78. doi:10.1007/s12040-021-01608-z

Ratnagar, S. (2002). The End of the Great Harappan Tradition. New Delhi, India: Manohar Publishers and Distributors.

Roland, T. P., Caseldine, C. J., Charman, D. J., Turney, C. S. M., and Amesbury, M. J. (2014). Was There a '4.2 Ka Event' in Great Britain and Ireland? Evidence from the Peatland Record. Quat. Sci. Rev. 83, 11-27. doi:10.1016/ j.quascirev.2013.10.024

Samanta, A. K., Kolte, A. P., Senani, S., Sridhar, M., and Jayapal, N. (2011). Prebiotics in Ancient Indian Diets. Curr. Sci. 101 (1), 43-46.

Saraswat, R., Lea, D. W., Nigam, R., Mackensen, A., and Naik, D. K. (2013). Deglaciation in the Tropical Indian Ocean Driven by Interplay between the Regional Monsoon and Global Teleconnections. Earth Planet. Sci. Lett. 375, 166-175. doi:10.1016/j.epsl.2013.05.022

Sarkar, A., Mukherjee, A. D., Bera, M. K., Das, B., Juyal, N., Morthekai, P., et al. (2016). Oxygen Isotope in Archaeological Bioapatites from India: Implications to Climate Change and Decline of Bronze Age Harappan Civilization. Sci. Rep. 6, 26555. doi:10.1038/srep26555

Schumm, S. A. (2007). River Variability and Complexity. Cambridge: Cambridge University Press.

Sengupta, T., Deshpande Mukherjee, A., Bhushan, R., Ram, F., Bera, M. K., Raj, H., et al. (2020). Did the Harappan Settlement of Dholavira (India) Collapse during the Onset of Meghalayan Stage Drought? J. Quat. Sci 35, 382-395. doi:10.1002/ jqs. 3178

Seppä, H., Bjune, A. E., Telford, R. J., Birks, H. J. B., and Veski, S. (2009). Last NineThousand Years of Temperature Variability in Northern Europe. Clim. Past 5, 523-535. doi:10.5194/cp-5-523-2009

Sha, L., Mahata, S., Duan, P., Luz, B., Zhang, P., Baker, J., et al. (2020). A Novel Application of Triple Oxygen Isotope Ratios of Speleothems. Geochimica et Cosmochimica Acta 270, 360-378. doi:10.1016/j.gca.2019.12.003

Sharma, C. P., Chahal, P., Kumar, A., Singhal, S., Sundriyal, Y., Ziegler, A. D., et al. (2021). Late Pleistocene-Holocene Flood History, Flood-Sediment Provenance and Human Imprints from the Upper Indus River Catchment, Ladakh Himalaya. GSA Bull. doi:10.1130/B35976.1

Shewale, M. P., and Kumar, S. (2005). Climatological Features of Drought Incidences in India. Pune, India: India Meteorological Department Pune.

Singh, D., Horton, D. E., Tsiang, M., Haugen, M., Ashfaq, M., Mei, R., et al. (2014). Severe Precipitation in Northern India in June 2013: Causes, Historical Context, and Changes in Probability. Bull. Amer. Meteorol. Soc. 95 (9), S58-S61.

Singh, G., Wasson, R. J., and Agrawal, D. P. (1990). Vegetational and Seasonal Climatic Changes since the Last Full Glacial in the Thar Desert, Northwestern India. Rev. Palaeobotany Palynology 64, 351-358. doi:10.1016/0034-6667(90)90151-8

Singh, I. B., Sharma, S., Sharma, M., Srivastava, P., and Rajagopalan, G. (1999). Evidence of Human Occupation and Climate of $30 \mathrm{Ka}$ in the Alluviam of Southern Ganga Plain. Curr. Sci. 76 (7), 1022-1026. 
Singh, P. (2002). "The Neolithic Cultures of Northern and Eastern India,". Indian Archaeology in Retrospect: Prehistory. Editors S. Settar and R. Korisettar (New Delhi: Indian Council of Historical Research and Manohar Publishers), Vol. 1, 127-150.

Singhvi, A. K., and Kar, A. (1992). Thar Desert in Rajasthan. Bangalore: Geological Society of India.

Sinha, A., Kathayat, G., Cheng, H., Breitenbach, S. F. M., Berkelhammer, M., Mudelsee, M., et al. (2015). Trends and Oscillations in the Indian Summer Monsoon Rainfall over the Last Two Millennia. Nat. Commun. 6, 6309. doi:10.1038/ncomms 7309

Sinha, A., Stott, L., Berkelhammer, M., Cheng, H., Edwards, R. L., Buckley, B., et al. (2011). A Global Context for Megadroughts in Monsoon Asia during the Past Millennium. Quat. Sci. Rev. 30, 47-62. doi:10.1016/j.quascirev.2010.10.005

Sirocko, F., Sarnthein, M., Erlenkeuser, H., Lange, H., Arnold, M., and Duplessy, J. C. (1993). Century-scale Events in Monsoonal Climate over the Past 24,000 Years. Nature 364 (6435), 322-324. doi:10.1038/364322a0

Sridhar, A., Laskar, A., Prasad, V., Sharma, A., Tripathi, J. K., Balaji, D., et al. (2015). Late Holocene Flooding History of a Tropical River in Western India in Response to Southwest Monsoon Fluctuations: A Multi Proxy Study from Lower Narmada valley. Quat. Int. 371, 181-190. doi:10.1016/j.quaint.2014.10.052

Stanley, J.-D., Krom, M. D., Cliff, R. A., and Woodward, J. C. (2003). Short Contribution: Nile Flow Failure at the End of the Old Kingdom, Egypt: Strontium Isotopic and Petrologic Evidence. Geoarchaeology 18 (3), 395-402. doi:10.1002/gea.10065

Staubwasser, M., Sirocko, F., and Grootes, P. M. (2003). Climate Change at the 4.2 Ka BP Termination of the Indus valley Civilization and Holocene South Asian Monsoon Variability. Geophys. Res. Lett. 30 (8), 016822. doi:10.1029/2002gl016822

Staubwasser, M., Sirocko, F., Grootes, P. M., and Erlenkeuser, H. (2002). South Asian Monsoon Climate Change and Radiocarbon in the Arabian Sea during Early and Middle Holocene. Paleoceanography 17 (4), 1063. doi:10.1029/2000pa000608

Staubwasser, M., and Weiss, H. (2006). Holocene Climate and Cultural Evolution in Late Prehistoric-Early Historic West Asia. Quat. Res. 66, 372-387. doi:10.1016/j.yqres.2006.09.001

Thiagarajan, N., Subhas, A. V., Southon, J. R., Eiler, J. M., and Adkins, J. F. (2014). Abrupt Pre-bølling-allerød Warming and Circulation Changes in the Deep Ocean. Nature 511 (7507), 75-78. doi:10.1038/nature13472

Thomas, E. R., Wolff, E. W., Mulvaney, R., Steffensen, J. P., Johnsen, S. J., Arrowsmith, K., et al. (2007). The 8.2ka Event from Greenland Ice Cores. Quat. Sci. Rev. 26 (1-2), 70-81. doi:10.1016/j.quascirev.2006.07.017

Tiwari, M., Nagoji, S. S., and Ganeshram, R. S. (2015). Multi-centennial Scale SST and Indian Summer Monsoon Precipitation Variability since the Mid-holocene and its Nonlinear Response to Solar Activity. The Holocene 25 (9), 1415-1424. doi:10.1177/0959683615585840

Tripati, A. K., Sahany, S., Pittman, D., Eagle, R. A., Neelin, J. D., Mitchell, J. L., et al. (2014). Modern and Glacial Tropical Snowlines Controlled by Sea Surface Temperature and Atmospheric Mixing. Nat. Geosci 7, 205-209. doi:10.1038/ ngeo2082

van der Plicht, J., Akkermans, P. M. M. G., Nieuwenhuyse, O., Kaneda, A., and Russell, A. (2011). Tell Sabi Abyad, Syria: Radiocarbon Chronology, Cultural Change, and the 8.2 Ka Event. Radiocarbon 53 (2), 229-243. doi:10.1017/ s0033822200056514

von Rad, U., Schaaf, M., Michels, K. H., Schulz, H., Berger, W. H., and Sirocko, F. (1999). A 5000-yr Record of Climate Change in Varved Sediments from the Oxygen Minimum Zone off Pakistan, Northeastern Arabian Sea. Quat. Res. 51, 39-53. doi:10.1006/qres.1998.2016

Walker, M., Gibbard, P., Head, M. J., Berkelhammer, M., Björck, S., Cheng, H., et al. (2019). Formal Subdivision of the Holocene Series/epoch: A Summary. J. Geol. Soc. India 93 (2), 135-141. doi:10.1007/s12594-019-1141-9

Walker, M., Head, M. J., Berkelhammer, M., Björck, S., Cheng, H., Cwynar, L., et al. (2018). Formal Ratification of the Subdivision of the Holocene Series/Epoch (Quaternary System/Period): Two New Global Boundary Stratotype Sections and Points (GSSPs) and Three New Stages/subseries. Episodes 41 (4), 213-223. doi:10.18814/epiiugs/2018/018016

Wang, Y., Cheng, H., Edwards, R. L., He, Y., Kong, X., An, Z., et al. (2005). The Holocene Asian Monsoon: Links to Solar Changes and North Atlantic Climate. Science 308 (5723), 854-857. doi:10.1126/science.1106296

Webster, P. J., Magaña, V. O., Palmer, T. N., Shukla, J., Tomas, R. A., Yanai, M., et al. (1998). Monsoons: Processes, Predictability, and the Prospects for Prediction. J. Geophys. Res. Oceans 103. doi:10.1029/97jc02719
Weiss, H., Courty, M.-A., Wetterstrom, W., Guichard, F., Senior, L., Meadow, R., et al. (1993). The Genesis and Collapse of Third Millennium North Mesopotamian Civilization. Science 261, 995-1004. doi:10.1126/science.261.5124.995

Weiss, H. (2016). Global Megadrought, Societal Collapse and Resilience at 4.2-3.9 Ka BP across the Mediterranean and West Asia. PAGES Mag. 24, 62-63. doi:10.22498/pages.24.2.62

Weiss, H., Manning, S. W., Ristvet, L., Marl, L., Besonen, M., Mccarthy, A., et al. (2012). "Tell Leilan Akkadian Imperialization, Collapse, and Short-Lived Reoccupation Defined by High-Resolution Radiocarbon Dating," in Seven Generations since the Fall of Akkad. Editor H. Weiss (Wiesbaden: Harrassowitz Verlag, 163-192.

Weninger, B., Alram-Stern, E., Bauer, E., Clare, L., Danzeglocke, U., Jöris, O., et al. (2006). Climate Forcing Due to the 8200 Cal Yr BP Event Observed at Early Neolithic Sites in the Eastern Mediterranean. Quat. Res. 66, 401-420. doi:10.1016/j.yqres.2006.06.009

Wicks, K., and Mithen, S. (2014). The Impact of the Abrupt 8.2 Ka Cold Event on the Mesolithic Population of Western Scotland: a Bayesian Chronological Analysis Using 'activity Events' as a Population Proxy. J. Archaeological Sci. 45, 240-269. doi:10.1016/j.jas.2014.02.003

Witzel, M. (1987). in India and the Ancient World. History, Trade and Culture before A.D. 650. Orientalia Lovaniensia Analecta Leuven. Editors P. H. L. Eggermont Jubilee Volume and G. Pollet, 25, 173-213 .

Wolff, E. W., Chappellaz, J., Blunier, T., Rasmussen, S. O., and Svensson, A. (2010). Millennial-scale Variability during the Last Glacial: The Ice Core Record. Quat. Sci. Rev. 29, 2828-2838. doi:10.1016/j.quascirev.2009.10.013

Wright, R. P., Bryson, R. A., and Schuldenrein, J. (2008). Water Supply and History: Harappa and the Beas Regional Survey. Antiquity 82, 37-48. doi:10.1017/s0003598x00096423

Wright, R. P. (2009). The Ancient Indus: Urbanism Economy, and Society. Cambridge University Press.

Yadav, R. R. (2009). Tree Ring Imprints of Long-Term Changes in Climate in Western Himalaya, India. J. Biosci. 34, 699-707. doi:10.1007/s12038-0090058-7

Yadav, R. R. (2013). Tree Ring-Based Seven-century Drought Records for the Western Himalaya, India. J. Geophys. Res. Atmos. 118, 4318-4325. doi:10.1002/ jgrd.50265

Yadava, M. G., and Ramesh, R. (2005). Monsoon Reconstruction from Radiocarbon Dated Tropical Indian Speleothems. The Holocene 15 (1), 48-59. doi:10.1191/0959683605h1783rp

Yadava, M. G., Ramesh, R., and Pant, G. B. (2004). Past Monsoon Rainfall Variations in Peninsular India Recorded in a 331-Year-Old Speleothem. The Holocene 14 (4), 517-524. doi:10.1191/0959683604hl728rp

Yadava, M. G., Sarswat, K. S., Singh, I. B., and Ramesh, R. (2007). Evidences of Early Human Occupation in the limestone Cave of Bastar, Chhattisgarh. Curr. Sci. 92 (6), 820.

Zanchetta, G., Regattieri, E., Isola, I., Drysdale, R. N., Bini, M., Baneschi, I., et al. (2016). The So-Called "4.2 Event" in the central Mediterranean and its Climatic Teleconnections. Alpine Mediterr. Quat. 29, 5-17.

Zanchetta, G., van Welden, A., Baneschi, I., Drysdale, R., Sadori, L., Roberts, N., et al. (2016). Multiproxy Record for the Last 4500 Years from Lake Shkodra (Albania/Montenegro). J. Quat. Sci. 27, 780-789. doi:10.1002/jqs.2563

Conflict of Interest: The authors declare that the research was conducted in the absence of any commercial or financial relationships that could be construed as a potential conflict of interest.

Publisher's Note: All claims expressed in this article are solely those of the authors and do not necessarily represent those of their affiliated organizations, or those of the publisher, the editors, and the reviewers. Any product that may be evaluated in this article, or claim that may be made by its manufacturer, is not guaranteed or endorsed by the publisher.

Copyright $\odot 2021$ Laskar and Bohra. This is an open-access article distributed under the terms of the Creative Commons Attribution License (CC BY). The use, distribution or reproduction in other forums is permitted, provided the original author(s) and the copyright owner(s) are credited and that the original publication in this journal is cited, in accordance with accepted academic practice. No use, distribution or reproduction is permitted which does not comply with these terms. 